\title{
Screening of Epiphytic Isolates from Different Crops for Plant Growth Promoting Traits
}

\author{
Raman Jangra $^{1}$, Satish Kumar ${ }^{1}$, Deepika Chaudhary ${ }^{1}$, Rashmi ${ }^{1}$, \\ Anju Kumari ${ }^{2}$ and Rakesh Kumar ${ }^{*}$ \\ ${ }^{1}$ Department of Microbiology, CCS Haryana Agriculture University, Hisar-125004, \\ Haryana, India \\ ${ }^{2}$ Centre of Food Science and Technology, CCS Haryana Agriculture University, Hisar- \\ 125004, Haryana, India \\ *Corresponding author
}

\section{A B S T R A C T}

Keywords

Zn, Epiphyte, Crop, IAA, Ammonia, P

Article Info

Accepted:

10 March 2018

Available Online:

10 April 2018
The role of $\mathrm{Zn}$ as micronutrient in healthy growth of plants is very important. The microorganisms present in phyllospheric environment have capability to increase micronutrient availability to plants. Total forty eight isolates were obtained from five different crops (wheat, mustard, cotton, pearl millet and moong). All isolates were characterized for different plant growth promoting attributes i.e., production of ammonia, IAA, and solubilization of Zinc, Phosphate. Among all isolates total $87.5 \%$ showed IAA and Ammonia production in different range. Total $72.91 \% \mathrm{Zn}$ solubalization and $60.41 \%$ $\mathrm{P}$ solubalization showed by isolates respectively. These plant growth promoting attributes are helpful in enhancing crop productivity. So these can be used as bioinoculant or as spray in crops.

\section{Introduction}

Microorganisms are present in soil, near and above the roots and also present on aerial part of plants like leaves. Ruinen (1961) introduced term phyllosphere for plant leaf surface. The termed epiphytes used for inhabitants of phyllosphere. The diverse range of bacteria, filamentous fungi, yeasts and algae which are important for plant health and growth are present on phyllosphere (Whipps et al., 2008; Vorholt, 2012). The total count of microbes approximately is about $6.4 \times 10^{8} \mathrm{~km}^{2}$ (Morris and Kinkel, 2002) in which each $\mathrm{km}^{2}$ is estimated to harbor $10^{16}-10^{18}$ bacteria
(Bulgerelli et al., 2013) on leaf surface. Phyllospheric microbes have important role in growth promotion of plants due to their ability to produce different plant growth hormone; production of antibiotic compounds which role in plant protection (Berg, 2009). Zinc as micronutrient have also significant role in different metabolic processes i.e., carbohydrate, lipid, nucleic acid and protein synthesis as well as their degradation. $\mathrm{Zn}$ is an integral component of many enzyme structures and also present in all six enzyme classes, i.e. oxidoreductases, transferases, hydrolases, lyases, isomerases, and ligases. Zinc is also role in control synthesis of indole 
acetic acid, chlorophyll synthesis and carbohydrate formation. It is part of phosphatase enzyme structure so its role in native phosphorous nutrient mobilization in rhizosphere also. Keeping in the view, the importance of zinc and Phyllospheric microbes this investigation was carried out. Isolation of phyllosphere microbes from different leaves of crops were carried out. These all isolates were checked for their plant growth promoting traits.

\section{Materials and Methods}

Isolation from phyllosphere of different crops

Different bacteria were isolated from the phyllosphere of different crops (wheat, mustard, cotton, moong and Pearl millet) grown at CCS HAU research farm. Different type of medium i.e., nutrient agar, Luria Bertani and Jensen's $\mathrm{N}_{2}$ free medium were used for isolation. Based on the morphological appearance, different bacterial colonies were selected, maintained and purified on respective medium slants. Cultures were stored at $4^{0} \mathrm{C}$ for further studies.

\section{Plant growth promoting traits}

Quantitative estimation of the indole acetic acid (IAA) was carried out by inoculating $1 \mathrm{ml}$ of the respective bacterial suspension in $10 \mathrm{ml}$ respective broth containing L-tryptophan (100 $\mu \mathrm{g} \mathrm{ml}^{-1}$ ), and incubating it in the dark for $96 \mathrm{~h}$. The concentration of IAA in the culture supernatant was estimated by the procedure of Salkowski's method (Glickmann and Dessaux, 1995). All the isolates were tested for their ability to excrete ammonia by growing the cultures in $30 \mathrm{ml}$ respective broths. Ammonia released in the supernatant was determined according to the method of Chaney and Marbach (1962). Solubilisation of zinc were assessed according to the procedure of
Saravanan et al., (2007) using nutrient agar medium containing $0.1 \%$ insoluble zinc compounds $\left[\mathrm{ZnO}, \quad \mathrm{ZnS}, \quad \mathrm{Zn}_{3}\left(\mathrm{PO}_{4}\right)_{2}\right.$ and $\mathrm{ZnCO}_{3}$ ], respectively solubilization index was calculated. Phosphorus solubilization was tested on Pikovskaya s agar plates. Five $\mu l$ of each culture broth was taken and spotted on these plates. These plates were incubated at $28 \pm 2{ }^{\circ} \mathrm{C}$ for 4 days in a BOD incubator and observed for P-solubilization zone. Zone of solubilization and colony diameter were measured. Solubilization index was calculated using the following formula:

Solubilization index $=(0.5 \mathrm{H})^{2} /(0.5 \mathrm{~A})^{2}$

$\mathrm{A}=$ Colony diameter

$\mathrm{H}=$ Diameter (Colony + Halo zone)

\section{Results and Discussion}

\section{Isolation of bacteria from the phyllosphere of different crops}

Total forty eight isolates from leaves of wheat, mustard, cotton, pearl millet and moong were isolated. These isolates obtained on three types of medium nutrient agar, Luria Bertani and Jensen's $\mathrm{N}_{2}$ free media were used (Table 1). Phyllosphere population include all type of microbes like different genera of bacteria, filamentous fungi, yeasts, algae, and less frequently, protozoa and nematodes. These have important role in plant health and growth promotion (Whipps et al., 2008; Vorholt, 2012). The epiphyte population is dominated by bacteria ranging from $10^{5}$ to $10^{7}$ cells per gram of plant material (Yadav et al., 2005).

\section{Screening of epiphytic isolates for plant growth promoting traits}

Total $87.5 \%$ isolates were showed ammonia and IAA production. The range of Ammonia production vary from $0.109-4.890 \mu \mathrm{g} / \mathrm{ml}$. Highest ammonia excretion was observed in 
isolate COJ1 $(4.890 \mu \mathrm{g} / \mathrm{ml})$ followed by WHN2 $(3.208 \mu \mathrm{g} / \mathrm{ml}$ ) isolate (Table 2$)$.

Ammonia is the immediate product of nitrogen fixation in nitrogen fixing microorganisms. Narula et al., (1981) and Chandna (1982) reported that wild strains of $A$. chroococcum are able to release ammonia in medium containing $1 \%$ sucrose as a carbon source. Lakshaminarayana et al., (2000) reported that diazotroph like Azotobacter had good capability of conversion of nitrogen to ammonia. Inoculation of maize and wheat with ammonia excreting bacteria (Azotobacter and Azospirillum) increased plant growth, nutrient uptake, yield and development of lateral roots (Rolfe et al., 1997; Dobbeleare et al., 2001; Ozturk et al., 2003).

The range of IAA production from 0.029 $28.173 \mu \mathrm{g} / \mathrm{ml}$ vary. The highest IAA production was observed in isolate $\mathrm{MNJ} 1$ $(28.173 \mu \mathrm{g} / \mathrm{ml})$ followed by WHL6 that produced $25.199 \mu \mathrm{g} \mathrm{IAA} / \mathrm{ml}$ after 4 days of incubation at $28 \pm 2^{\circ} \mathrm{C}$ (Table 2). The IAA production varies with species, strains and growth conditions (Pathak et al., 1995). Five major classes of phytohormones i.e., auxin, gibberlins, eyhylene, cytokinins and abscisic acid are role in plant growth hormone. IAA is a member of auxin family, influences plant growth (Tsakelova et al., 2006).

Fig.1 Zinc solubilization zone shown by bacterial isolates on

MM agar plates containing zinc oxide

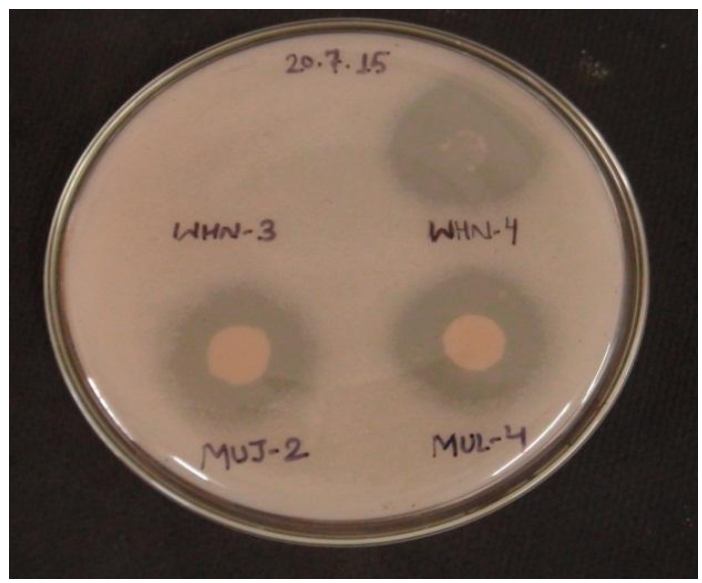

Fig.2 Phosphate solubilization zone shown by bacterial isolates on Pikovskaya's agar plates

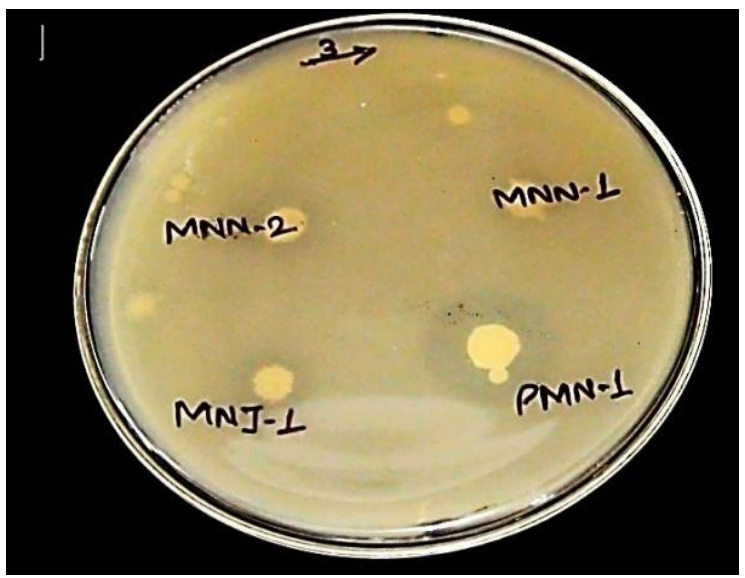


Table.1 List of bacteria isolated from phyllosphere of different crops

\begin{tabular}{|c|c|c|c|c|}
\hline \multirow{2}{*}{$\begin{array}{c}\text { Site of } \\
\text { collection of } \\
\text { leaves } \\
\text { samples }\end{array}$} & \multicolumn{3}{|c|}{ Medium used for isolation } & \multirow{2}{*}{$\begin{array}{l}\text { No. of } \\
\text { isolates }\end{array}$} \\
\hline & Nutrient agar & Luria Bertani & $\begin{array}{l}\text { Jensen's } \mathbf{N}_{2} \\
\text { free medium }\end{array}$ & \\
\hline $\begin{array}{c}\text { Wheat } \\
\text { phyllosphere } \\
\text { HAU } \\
\text { research } \\
\text { farm, Hisar }\end{array}$ & $\begin{array}{c}\text { WHN1,WHN2, } \\
\text { WHN3,WHN4,WHN5, } \\
\text { WHN6,WHN7, WHN8 }\end{array}$ & $\begin{array}{l}\text { WHL1, WHL2,WHL3, WHL4, } \\
\text { WHL5, WHL6, WHL7 }\end{array}$ & $\begin{array}{l}\text { WHJ1, WHJ2, } \\
\text { WHJ3, WHJ4, } \\
\text { WHJ5, WHJ6, } \\
\text { WHJ7, WHJ8 }\end{array}$ & 23 \\
\hline $\begin{array}{c}\text { Mustard } \\
\text { phyllosphere } \\
\text { HAU } \\
\text { research } \\
\text { farm, Hisar }\end{array}$ & MUN1 & MUL1,MUL2,MUL3, MUL4 & MUJ1, MUJ2 & 7 \\
\hline $\begin{array}{c}\text { Cotton } \\
\text { phyllosphere } \\
\text { HAU } \\
\text { research } \\
\text { farm, Hisar }\end{array}$ & CON1, CON2 & $\mathrm{COL} 1, \mathrm{COL} 2, \mathrm{COL} 3, \mathrm{COL} 4$ & COJ1, COJ2 & 8 \\
\hline $\begin{array}{l}\text { Pearl millet } \\
\text { phyllosphere } \\
\text { HAU } \\
\text { research } \\
\text { farm, Hisar }\end{array}$ & PMN1 & PML1, PML2 & PMJ1, PMJ2 & 5 \\
\hline $\begin{array}{c}\text { Moong } \\
\text { phyllosphere } \\
\text { HAU } \\
\text { research } \\
\text { farm, Hisar }\end{array}$ & MNN1, MNN2 & MNL1, MNL2 & MNJ1 & 5 \\
\hline $\begin{array}{l}\text { Total no. of } \\
\text { isolates }\end{array}$ & 14 & 19 & 15 & 48 \\
\hline
\end{tabular}

Table.2 Characterization of bacterial isolates for plant growth promoting traits

\begin{tabular}{|c|c|c|c|c|c|}
\hline $\begin{array}{c}\text { Isolate } \\
\text { no. }\end{array}$ & $\begin{array}{c}\text { Source } \\
\text { (phyllosphere) }\end{array}$ & $\begin{array}{c}\mathbf{N H}_{3} \text { Excretion } \\
\left(\boldsymbol{\mu g} \mathbf{~ m}^{-1}\right)\end{array}$ & $\begin{array}{c}\text { IAA } \\
\text { Producti } \\
\text { on }(\boldsymbol{\mu g} \\
\left.\mathbf{m l}^{-1}\right)\end{array}$ & $\begin{array}{c}\text { Zinc } \\
\text { Solubilization } \\
\text { index }\end{array}$ & $\begin{array}{c}\text { Phosphate } \\
\text { Solubilization index }\end{array}$ \\
\hline WHL-1 & Wheat & 2.76 & 13.77 & - & - \\
\hline WHL-2 & Wheat & 2.15 & 14.35 & - & - \\
\hline WHL-3 & Wheat & 1.56 & 6.79 & 1.71 & 2.94 \\
\hline WHL-4 & Wheat & 2.61 & 8.31 & 4.06 & - \\
\hline WHL-5 & Wheat & 0.10 & 15.60 & - & - \\
\hline WHL-6 & Wheat & 1.75 & 25.20 & - & - \\
\hline & & & 1060 & & \\
\hline
\end{tabular}




\begin{tabular}{|c|c|c|c|c|c|}
\hline WHL-7 & Wheat & 1.98 & 3.06 & - & - \\
\hline MUL-1 & Mustard & - & 3.06 & - & - \\
\hline MUL-2 & Mustard & 0.97 & 7.41 & - & - \\
\hline MUL-3 & Mustard & 1.38 & 24.20 & 3.24 & - \\
\hline MUL-4 & Mustard & 1.14 & 2.39 & 5.76 & 2.64 \\
\hline COL-1 & Cotton & 0.50 & 3.44 & 4.00 & 16.00 \\
\hline COL-2 & Cotton & 0.50 & 22.10 & 4.00 & 9.00 \\
\hline COL-3 & Cotton & 0.98 & 3.90 & 2.12 & 12.96 \\
\hline COL-4 & Cotton & 0.99 & 4.55 & - & - \\
\hline PML-1 & Pearl Millet & 0.78 & - & - & - \\
\hline PML-2 & Pearl Millet & 1.134 & 0.03 & - & - \\
\hline MNL-1 & Moong & 1.12 & 10.18 & 0.90 & 2.09 \\
\hline MNL-2 & Moong & 1.92 & 8.31 & 2.25 & 2.42 \\
\hline WHJ-1 & Wheat & - & 2.33 & 8.16 & 1.44 \\
\hline WHJ-2 & Wheat & 0.67 & 7.00 & 5.06 & - \\
\hline WHJ-3 & Wheat & - & 8.49 & 5.29 & - \\
\hline WHJ-4 & Wheat & 0.98 & 8.14 & 12.75 & 5.06 \\
\hline WHJ-5 & Wheat & 0.98 & 2.48 & 4.84 & 2.25 \\
\hline WHJ-6 & Wheat & - & 0.26 & - & - \\
\hline WHJ-7 & Wheat & 0.20 & 0.44 & 6.53 & - \\
\hline WHJ-8 & Wheat & 1.27 & 3.20 & 5.29 & 1.69 \\
\hline MUJ-1 & Mustard & 1.27 & 3.27 & 5.76 & - \\
\hline MUJ-2 & Mustard & 1.14 & - & 7.84 & 1.56 \\
\hline COJ-1 & Cotton & 4.90 & 2.60 & 4.00 & 9.00 \\
\hline $\mathrm{COJ}-2$ & Cotton & 2.74 & 7.99 & 7.84 & 4.84 \\
\hline PMJ-1 & Pearl Millet & 1.98 & 4.46 & 2.98 & 4.84 \\
\hline PMJ-2 & Pearl Millet & 2.00 & 1.66 & 1.85 & 6.61 \\
\hline PML-2 & Pearl Millet & 1.134 & 0.03 & - & - \\
\hline MNL-1 & Moong & 1.12 & 10.18 & 0.90 & 2.09 \\
\hline MNL-2 & Moong & 1.92 & 8.31 & 2.25 & 2.42 \\
\hline WHJ-1 & Wheat & - & 2.33 & 8.16 & 1.44 \\
\hline WHJ-2 & Wheat & 0.67 & 7.00 & 5.06 & - \\
\hline WHJ-3 & Wheat & - & 8.49 & 5.29 & - \\
\hline WHJ-4 & Wheat & 0.98 & 8.14 & 12.75 & 5.06 \\
\hline WHJ-5 & Wheat & 0.98 & 2.48 & 4.84 & 2.25 \\
\hline WHJ-6 & Wheat & - & 0.26 & - & - \\
\hline WHJ-7 & Wheat & 0.20 & 0.44 & 6.53 & - \\
\hline WHJ-8 & Wheat & 1.27 & 3.20 & 5.29 & 1.69 \\
\hline MUJ-1 & Mustard & 1.27 & 3.27 & 5.76 & - \\
\hline MUJ-2 & Mustard & 1.14 & - & 7.84 & 1.56 \\
\hline $\mathrm{COJ}-1$ & Cotton & 4.90 & 2.60 & 4.00 & 9.00 \\
\hline $\mathrm{COJ}-2$ & Cotton & 2.74 & 7.99 & 7.84 & 4.84 \\
\hline PMJ-1 & Pearl Millet & 1.98 & 4.46 & 2.98 & 4.84 \\
\hline PMJ-2 & Pearl Millet & 2.00 & 1.66 & 1.85 & 6.61 \\
\hline
\end{tabular}

- = ND (Not Detectable) 
Kannapiran and Ramkumar (2011) tested 17 bacterial isolates including Azotobacter chroococcum, Azotobacter beijerinckii, Pseudomonas aeruginosa and Bacillus sp. for indole acetic acid production in vitro. Among these isolates, amount of IAA produced by Azotobacter chroococcum and Azotobacter beijerinckii were 23.6 and $17.6 \mu \mathrm{g} \mathrm{ml}$ respectively.

All the isolates were screened for zinc solubilization on minimal medium (MM) agar plates containing insoluble zinc source i.e. zinc oxide. Solubilization potential for each isolate was determined by measuring zone of solubilization. Zinc solubilization index varied from 0.34 - 37.05 (Fig. 1). Isolate MNN1 showed highest Zn solubilization index (37.05) followed by MNN2 (31.94) (Table 2). Saravanan et al., (2003) also assessed zinc solubilizing ability of Bacillus sp. (isolated from zinc ore) and Pseudomonas sp. (isolated from paddy soil) using zinc oxide, zinc sulphide and zinc carbonate in both plate and broth assays. ZSB-O-1 isolate (Bacillus sp.) showed highest dissolution in the zinc sulfide (Sphalerite ore) and ZSB-S-2 (Pseudomonas sp.) showed more solubilizing ability in the zinc oxide. Sharma et al., (2014) also screened forty eight endophytic bacteria isolated from soybean and summer mungbean rhizosphere for zinc solubilizing ability in Tris- minimal medium separately amended with inorganic zinc compounds viz. zinc oxide $(\mathrm{ZnO})$ and zinc phosphate $\mathrm{Zn}_{3}\left(\mathrm{PO}_{4}\right)_{2}$ by plate assay method and observed that only 2 isolates solubilized $\mathrm{ZnO}$ whereas 2 isolates solubilized $\mathrm{Zn}_{3}\left(\mathrm{PO}_{4}\right)_{2}$.

Indian soils are normally deficient in available phosphorus. A large portion of the soil phosphorus (P) is in unavailable form, which should be solubilized so that plants can use it. Also, phosphate solubilizing bacteria are able to mobilize more phosphorus to the plants and improve plant growth
(Egamberdiyeva et al., 2004). Thus keeping in view importance of $\mathrm{P}$ for the plants, bacterial isolates were checked for phosphate solubilization. Twenty nine bacterial isolates solubilized phosphate with an index ranging from 0.53 - 18.78 (Fig. 2). Highest phosphate solubilization index was observed in isolate PMN1 (18.78) followed by isolate COL3 (12.96) (Table 2). Woo et al., (2010) isolated phosphate solubilizing bacterial isolates from the rhizosphere of Chinese cabbage and found that 10 strains which were having higher solubilization potential also solubilized insoluble ZnO. Duangpaeng et al., (2012) isolated five endophytic bacteria that solubilized tricalcium phosphate in Pikovskaya's agar. Solubilization index of CHR3I01， BRR1I04， BRR3I01， CHR4I07 and CHR2I02 were 10.0, 7.0, 3.9, 3.2 and 2.7 respectively. Chandrasekeran and Mahalingam (2014) collected the rhizosphere soil samples and processed for the presence of phosphate solubilizing microorganisms. The maximum solubilization index and inorganic phosphorus production was with Bacillus sp. and Micrococcus sp.

\section{References}

Berg, G. 2009. Plant-microbe interactions promoting plant growth and health: perspectives for controlled use of microorganisms in agriculture. Appl. Microbiol. Biotechnol, 84: 11-18.

Bulgarelli, D., Schlaeppi, K., Spaepen, S., Themaat, E and Lefert, P. 2013. Structure and functions of the bacterial microbiota of plants. Annu. Rev. Plant Biol., 64: 807-838.

Chandna, S. 1982. Mechanism of ammonia excretion in Azotobacter chroococcum. M. Sc. Thesis, Dept. of Microbiology, CCS HAU, Hisar.

Chandrasekeran, A. and Mahalingam, P.U. 2014. Isolation of phosphate solubilizing bacteria from sorghum 
bicolor rhizosphere soil inoculated with arbuscular mycorrhizae fungi (Glomus sp). Res. Biotechnol., 5: 01-05.

Chaney, A.L. and Marbach, E.P. 1962. Methods for evaluating biological nitrogen fixation (ed F.J. Bergersen) John Wiley and sons, New York. Clin. Chem., 8: 130.

Dobbelaere, S., Croonenborghs, A., Thys, A., Ptacok, D., Vanderbyden, J., Dutto, P., Labendera-Gonzzalez, C., CaballeroMellado, J., Agirre, F., Kapulnik, Y., Brener, S., Burdman, S., Kadouri, D., Sarig, S. and Okon, Y. 2001. Response of agronomically important crops to inoculatin with Azospirillum. Aust. J. Plant Physiol., 28: 871-879.

Duangpaeng, A., Phetcharat, P., Chanthapho, S., Boonkantong, N. and Okuda, N. 2012. The study and development of endophytic bacteria for enhancing organic rice growth. Procedia Eng., 32: 172-176.

Egamberdiyeva, D., Juraeva, D., Poberejskaya, S., Myachina, O., Teryuhova, P., Seydalieva, L. and Aliev, A. 2004. Improvement of wheat and cotton growth and nutrient uptake by phosphate solubilizing bacteria. Proceedings of the 26th Southern Conservation Tillage Conference for Sustainable Agriculture, Raleigh, North Carolina, USA, 8-9 June Pp. 58-66.

Glickmann, E., Garden, L., Jaeguet, S., Hussain, S., Elasri, M., Petit, A. and Dessaux, Y. 1998. Auxin production is a common feature of most pathovars of Pseudomonas syringae. Mol. Plant Microbe Interact., 11: 156-162.

Kannapiran, E. and Ramkumar, V.S. 2011. Inoculation effect of nitrogen-fixing and phosphate solubilizing bacteria to promote growth of black gram (Phaseolus mungo). Ann. Biol. Res., 2: 615-621.
Lakshminarayana, K., Shukla, B., Sindhu, S.S., Kumari, P., Narula, N. and Sheoran, R.K. 2000. Analouge resistant mutants of $A$. chroococcum depressed for nitrogenase activity and early ammonia excretion having potential as inoculants for cereal crops. Indian $J$. Exp. Biol., 38: 373-378.

Morris, C.E. and Kinkel, L.L. 2002. Fifty years of phylosphere microbiology: significant contributions to research in related fields. Phyllosphere Microbiology (eds S.E. Lindow, E.I. Hecht-Poinar, and V. Elliott), pp. 365375. APS Press, St. Paul, Minn.

Narula, N., Lakshminarayana, K. and Tauro, P. 1981. Ammonia excretion by $A$. chroococcum. Biotechnol. Bioeng., 23: 467-470.

Ozturk, A., Caglar, O. and Sahin, F. 2003. Yield response of wheat and barley to inoculation of plant growth promoting rhizobacteria at various levels of nitrogen fertilizers. J. Plant Nutr. Soil Sci., 166: 262-266.

Pathak, D.V., Lakshmninarayana, K. ANd Narula, N. 1995. Analogue resistant mutants of Azotobacter chroococcum affecting growth parameters in sunflower (Helianthus annus L.) under pot culture conditions. Sci. Lett., 18: 203-206.

Rolfe, B.G., Djordjevic, M.A., Weinmam, J.J., Mathesius, U., Pittock, C., Gartner, E., Ride, K.M., Dong, Z., Mccully, M. and Mclver, J. $1997 . \quad$ Root morphogenesis in legumes and cereals and the effect of bacterial inoculation on root development. Plant Soil., 194: 131144.

Ruinen, J. 1961. The Phylloshere. I. An Ecologically Neglected Mileau. Plant Soil., 15: 81-106.

Saravanan, V.S., Subramoniam, S.R. and Raj, S.A. 2003. Assessing in vitro solubilization potential of different zinc 
solubilizing bacterial (ZSB) isolates. Braz. J. Microbiol., 34: 121-125.

Sharma, P., Kumawat, K.C., Kaur, S. and Kaur, N. 2014. Assessment of zinc solubilization by endophytic bacteria in legume rhizosphere. Indian J. Appl. Res.

Tsavkelova, E.A., Klimova, S.Y., Cherdyntseva, T.A. and Netrusov, A.I. 2006. Microbial producers of plant growth stimulators and their practical use: a review. Appl. Biochem. Microbiol., 42: 117-126.

Vorholt, J.A. 2012. Microbial life in the phyllosphere. Nature Rev. Microbiol., 10: 828-840.

Whipps, J.M., Hand, P., Pink, D. and Bending, G.D. 2008. Phyllosphere microbiology with special reference to diversity and plant genotype. J. Appl. Microbiol., 105: 1744-1755.

Woo, S.M., Lee, M.K., Hong, I.S., Poonguzhali, S. and Sa, T.M. 2010. Isolation and characterization of phosphate solubilizing bacteria from Chinese cabbage. $19^{\text {th }}$ World Congress of Soil Science, Soil Solutions for a Changing World. pp. 361-763.

Yadav, R.K.P., Karamanoli, K. and Vokou, D. 2005. Bacterial colonization of the phyllosphere of Mediterranean perennial species as influenced by leaf structural and chemical features. Microb. Ecol., 50: 185-196.

\section{How to cite this article:}

Raman Jangra, Satish Kumar, Deepika Chaudhary, Rashmi, Anju Kumari and Rakesh Kumar. 2018. Screening of Epiphytic Isolates from Different Crops for Plant Growth Promoting Traits. Int.J.Curr.Microbiol.App.Sci. 7(04): 1057-1064. doi: https://doi.org/10.20546/ijcmas.2018.704.116 